\title{
Effect of Precision Farming Techniques Involving Fertigation and Mulching on Growth Attributes and Seed Yield of Okra Var. Arka Anamika [Abelmoschus esculentus (L.) Moench]
}

\author{
N.S. Nagegowda ${ }^{1}$, T. Senthivel ${ }^{2}$, S. Shankar Hebbar ${ }^{1}$ and M. Senthilkumar ${ }^{1}$ \\ ${ }^{1}$ Division of Vegetable Crops, ICAR-Indian Institute of Horticultural Research, \\ Bengaluru-560089, Karnataka, India \\ ${ }^{2}$ Department of Agriculture and Animal Husbandry, Gandhigram Rural Institute, \\ Gandhigram-624 302, Tamilnadu, India \\ *Corresponding author
}

\begin{abstract}
A B S T R A C T
Keywords

Okra,

Abelmoschus

esculentus (L.)

Moench

Article Info

Accepted:

18 January 2019

Available Online:

10 February 2019

An experiment was conducted during rabi 2016 to the study effect of precision farming technologies including fertigation and black polythene mulching to know the effect on growth, yield and quality of okra [Abelmoschus esculentus (L.) Moench] seeds var. Arka Anamika at ICAR-Indian institute of Horticultural Research Hesaraghatta, Bengaluru. The experiment consisted of ten treatments were laid out in a Randomised Block Design (RBD) with three replications. The maximum plant height $(115.52 \mathrm{~cm})$, number of branches (3.10), stem girth $(4.76 \mathrm{~cm})$, leaf area index $(2.76)$, number of dry pods per plant (14.33), weight of dry fruit $(10.33 \mathrm{~g})$ and seed yield $\left(15.30 \mathrm{q} \mathrm{ha}^{-1}\right)$ was recorded with $\mathrm{T}_{4}$ 150:75:150 N: $\mathrm{P}_{2} \mathrm{O}_{5}: \mathrm{K}_{2} \mathrm{O} \mathrm{kg} \mathrm{ha}{ }^{-1}$ applied through fertigation (WSF) with mulch over un mulched treatment. The increase of okra seed yield in mulched treatment over the unmulched treatments with fertigation was 16.91 per cent. Similarly the increase of seed yield under fertigation with un-mulched treatments over application of fertilizer through soil was 10.14 per cent.
\end{abstract}

\section{Introduction}

Okra (Abelmoschus esculentus L. Moench), also known as lady's finger or bhendi is an important vegetable crop belongs to family Malvaceae. Though okra finds its origin in South Africa, India stands top in area and production. It is grown practically in all agroecological zones of India mainly for its immature fruits which are eaten as cooked vegetable. Dried seeds are nutritious food. It contains up to 20 per cent protein and the fibre from okra fresh canes is a possible paper pulp source, while the dried canes are the source of fuel.

In India, presently $10.24 \mathrm{~m}$. ha area is cultivated with vegetable with an annual production of $178.30 \mathrm{~m}$. tons and the share of okra in total vegetable production is 3.4 per cent. The average national productivity of okra is around 11.8 tons/ha. It is estimated 
that by 2020 the vegetable requirement in the country would be around 210 million tons. To achieve this target, our attention must be focused on the vertical expansion blended with advanced technology instead of horizontal expansion just by increasing the crop area (Rai and Pandey, 2008). The working group on horticulture constituted by the planning commission had recommended deployment of hi-tech horticulture and precision farming for achieving vertical growth in horticulture. Hi-tech interventions in horticultural crops proposed by National Committee on Plasticulture Application in Horticulture (NCPAH), Govt. of India are drip irrigation and in situ moisture conservation through mulching (Samuel and Singh, 2004). Drip irrigation with its ability of small and frequent applications has created interest because of less water requirement, possible increased production and better quality of produce. Use of soil cover and mulching are also known to be beneficial through their influence on soil moisture conservation, solarisation and control of weeds. Benefits of using mulch includes early production, more yield and reduced insect and disease problems.

Burgeoning population and increasing urbanization have boosted the area of intensive cultivation of vegetables in periurban areas. In this context, the demand for good quality vegetable seeds becomes necessary to obtain healthy plants and yield. An estimated 11,000 hectares presently produce vegetable seed all over the country. A constant attention is bestowed globally on optimization of fertilizer management of vegetable purpose crops but no organized attention is paid to seed purpose vegetable crops. Good quality seed is one aspect that needs emphasis besides high yield of seed per se. In this context production of high quantities of good quality seeds in large number of vegetable crops over a significant area implies economic and ecological consideration at the national level. Obviously, precision farming technology has become a necessity for producing better quality seeds with much emphasis on precise fertilizer management targeting higher fruit yield, fertilizer use efficiency of $\mathrm{N}$ and $\mathrm{P}$, seed yield and quality.

\section{Materials and Methods}

The experiment was conducted during rabi 2016 to study the effect of precision farming technologies including fertigation and black polythene mulching to know the growth, yield and quality of okra [Abelmoschus esculentus (L.) Moench] seeds var. Arka Anamika at ICAR-IIHR, Hesaraghatta, Bengaluru. The experiment was laid out in RBD with three replication. The treatment details are as given below:

\section{Treatment details}

$\mathrm{T}_{1}-100: 50: 75 \mathrm{~N}: \mathrm{P}_{2} \mathrm{O}_{5}: \mathrm{K}_{2} \mathrm{O} \quad \mathrm{kg} \mathrm{ha}^{-1}$ through fertigation (WSF)) with mulch

$\mathrm{T}_{2}$-100:50:100 $\mathrm{N}: \mathrm{P}_{2} \mathrm{O}_{5}: \mathrm{K}_{2} \mathrm{O} \mathrm{kg} \mathrm{ha}{ }^{-1}$ through fertigation (WSF) with mulch

$\mathrm{T}_{3}-150: 75: 112.5 \mathrm{~N}: \mathrm{P}_{2} \mathrm{O}_{5}: \mathrm{K}_{2} \mathrm{O} \mathrm{kg} \mathrm{ha}{ }^{-1}$ through fertigation (WSF) with mulch

$\mathrm{T}_{4}-150: 75: 150 \mathrm{~N}: \mathrm{P}_{2} \mathrm{O}_{5}: \mathrm{K}_{2} \mathrm{O} \mathrm{kg} \mathrm{ha}{ }^{-1}$ through fertigation (WSF) with mulch

$\mathrm{T}_{5}-100: 50: 75 \mathrm{~N}: \mathrm{P}_{2} \mathrm{O}_{5}: \mathrm{K}_{2} \mathrm{O} \mathrm{kg} \mathrm{ha}^{-1}$ through fertigation (WSF) without mulch

$\mathrm{T}_{6}-100: 50: 100 \quad \mathrm{~N}: \mathrm{P}_{2} \mathrm{O}_{5}: \mathrm{K}_{2} \mathrm{O} \mathrm{kg} \mathrm{ha}{ }^{-1}$ through fertigation (WSF) without mulch

$\mathrm{T}_{7}-150: 75: 112.5 \mathrm{~N}: \mathrm{P}_{2} \mathrm{O}_{5}: \mathrm{K}_{2} \mathrm{O} \mathrm{kg} \mathrm{ha}{ }^{-1}$ through fertigation (WSF) without mulch

$\mathrm{T}_{8}-150: 75: 150 \mathrm{~N}: \mathrm{P}_{2} \mathrm{O}_{5}: \mathrm{K}_{2} \mathrm{O} \mathrm{kg} \mathrm{ha}^{-1}$ through fertigation (WSF) without mulch

$\mathrm{T}_{9}-100: 50: 100 \quad \mathrm{~N}: \mathrm{P}_{2} \mathrm{O}_{5}: \mathrm{K}_{2} \mathrm{O} \quad \mathrm{kg} \quad \mathrm{ha}^{-1}$ soil application of fertilizers without mulch

$\mathrm{T}_{10}-150: 75: 150 \quad \mathrm{~N}: \mathrm{P}_{2} \mathrm{O}_{5}: \mathrm{K}_{2} \mathrm{O} \quad \mathrm{kg} \quad \mathrm{ha}^{-1}$ soil application of fertilizers without mulch

(WSF-water soluble fertilizer) 
The experimental plots of $10.2 \mathrm{~m}(\mathrm{~L}) \times 3.6 \mathrm{~m}$ (W) were prepared for sowing the okra seeds. The row to row and plant to plant spacing were $0.60 \mathrm{~m}$ and $0.30 \mathrm{~m}$ respectively. Black polythene mulch of 30 micron thickness was used. Water soluble fertilizers viz., 19:19:19, urea and potassium nitrate were used for fertigation treatments whereas regular NPK fertilizers were applied through soil for the treatments $\mathrm{T}_{9}$ and $\mathrm{T} 10$ in the form of urea, $\mathrm{Di}$ ammonium phosphate (DAP) and muriate of potash (MOP) were used in two splits at 28 and 56 days after sowing in equal proportions. The water soluble fertilizers were injected in 16 equal splits at weekly interval and all other recommended cultural practices were followed in raising the crop.

\section{Results and Discussion}

Precision farming technology involving mulching and fertigation with NPK significantly influenced the growth characters such as plant height, number of branches per plant, stem girth, and yield attributes viz., number of pods per plant, weight of dry fruit. Seed yield was also influenced significantly by different fertigation and mulching treatments (Table 1). Application of fertilizer through fertigation exhibited significant effect on plant height, maximum plant height $(115.52 \mathrm{~cm})$ was recorded with $\mathrm{T}_{4}$ 150:75:150 N: $\mathrm{P}_{2} \mathrm{O}_{5}: \mathrm{K}_{2} \mathrm{O} \quad \mathrm{kg} \mathrm{ha}^{-1}$ through fertigation (WSF) with mulch, while the minimum plant height $(93.73 \mathrm{~cm})$ was recorded in the $\mathrm{T}_{9}-100: 50: 100 \mathrm{~N}: \mathrm{P}_{2} \mathrm{O}_{5}: \mathrm{K}_{2} \mathrm{O} \mathrm{kg}$ $\mathrm{ha}^{-1}$ soil applications of fertilizers without mulch. These findings are in line with the fertigation experiment of Sanchita et al., (2014) on capsicum. They reported that among different fertigation treatments 100 per cent recommended dose of $\mathrm{N}$ and $\mathrm{K}$ recorded highest vegetative growth in capsicum. The increased plant height of okra may be due to uniform availability of major nutrients through fertigation. The results of number of branches and stem girth increased significantly in fertigation treatments with mulch as compared to soil application of fertilizers without mulch. The present study revealed that the highest number of branches (3.10) and maximum stem girth $(4.76 \mathrm{~cm})$ were observed in the treatment $\mathrm{T}_{4^{-}}$ 150:75:150 N: $\mathrm{P}_{2} \mathrm{O}_{5}: \mathrm{K}_{2} \mathrm{O} \quad \mathrm{kg} \mathrm{ha}^{-1}$ through fertigation (WSF) with mulch compared to un-mulched treatments T8 with respect to number of branches (2.57) and stem girth $(4.13 \mathrm{~cm})$. However lowest number of branches (2.17) and stem girth $(3.93 \mathrm{~cm})$ were noticed in the treatment with application of fertilizer (100:75:150 N: $\mathrm{P}_{2} \mathrm{O}_{5}: \mathrm{K}_{2} \mathrm{O} \mathrm{kg} \mathrm{ha}{ }^{-1}$ ) through soil without mulch. Beneficial responses of vegetable crops to mulch in terms of growth and yield have been reported by Asiegbu, (1991), Shrivastava et al., (1994) and Tiwari et al., (1998) (Fig. 1).

From the table it was observed that the days to $50 \%$ flowering in mulched plots were same as that of control plot. Whereas, application of fertilizer through drip irrigation has taken maximum days (42.67 days) for flowering as compared to treatment $\mathrm{T}_{10}-100: 75: 150$ $\mathrm{N}: \mathrm{P}_{2} \mathrm{O}_{5}: \mathrm{K}_{2} \mathrm{O} \mathrm{kg} \mathrm{ha}^{-1}$ (soil application of fertilizers without mulch) which took (37.33 days) for flowering. This may be due to the reason that the early emergence of flowers is due to unfavourable moisture regime (moisture stress or excess moisture) as reported by Pattanaik et al., (2003) and Agrawal and Agrawal (2005). The earliness in flowering can also be attributed to simultaneous transport of growth substances like cytokinin to the auxillary bud breaking the apical dominance (Sharma, 2002; Hazarika and Ansari, 2010).

With respect to leaf area index, the highest leaf area index (2.76) was seen in the treatment with $\mathrm{T}_{4}-150: 75: 150 \quad \mathrm{~N}: \mathrm{P}_{2} \mathrm{O}_{5}: \mathrm{K}_{2} \mathrm{O}$ $\mathrm{kg} \mathrm{ha}^{-1}$ through fertigation (WSF) with mulch compared with un-mulched treatments $\mathrm{T}_{8}$ 
(2.37). Lowest leaf area index (1.09) was observed with application of fertilizer through soil 100:50:100 N: $\mathrm{P}_{2} \mathrm{O}_{5}: \mathrm{K}_{2} \mathrm{O} \mathrm{kg} \mathrm{ha}{ }^{-1}$ followed by application of 150:75:150 NPK $\mathrm{kg} \mathrm{ha}^{-1}$ through soil application without mulch (1.42). This result corroborated the findings of Thakur et al., (2000) that different mulching materials like grass, lantana and plastic helped bell pepper to perform better at water deficits from 25,50 and $75 \%$. The plant height, leaf area, leaf area index, number of flowers and fruit yield were significantly higher in mulched plants than the un- mulched ones up to $75 \%$ water deficit.

The yield and yield attributing characters were significantly influenced by fertigation and mulching treatments. The highest seed yield $\left(15.30 \mathrm{q} \mathrm{ha}^{-1}\right)$ was recorded in the treatment $\mathrm{T}_{4}-150: 75: 150 \mathrm{~N}: \mathrm{P}_{2} \mathrm{O}_{5}: \mathrm{K}_{2} \mathrm{O} \mathrm{kg} \mathrm{ha}^{-1}$ through fertigation (WSF) with mulch and on par with the treatment $\mathrm{T}_{3}-150: 75: 112.5$ $\mathrm{N}: \mathrm{P}_{2} \mathrm{O}_{5}: \mathrm{K}_{2} \mathrm{O} \mathrm{kg} \mathrm{ha}^{-1}$ through fertigation (WSF) with mulch $\left(14.02 \mathrm{q} \mathrm{ha}^{-1}\right)$ followed by $\mathrm{T}_{2}\left(11.51 \mathrm{q} \mathrm{ha}^{-1}\right)$ and $\mathrm{T}_{1}\left(12.28 \mathrm{q} \mathrm{ha}^{-1}\right)$ over the un-mulched treatments $\left(\mathrm{T}_{5^{-}} 10.17, \mathrm{~T}_{6^{-}}\right.$ 10.24, $\mathrm{T}_{7}-11.33$ and $\mathrm{T}_{8} 12.39 \mathrm{q} \mathrm{ha}^{-1}$ ). However, the lowest yield was observed in the treatment with application of fertilizer through soil $\left(\mathrm{T}_{9}-8.85\right.$ and $\left.\mathrm{T}_{10^{-}}-9.85 \mathrm{q} \mathrm{ha}^{-1}\right)$. The percentage increase of okra seed yield in mulched treatment over the un-mulched treatments with fertigation was 16.90 per cent. Similarly the percentage increase of seed yield fertigation with un-mulched treatments over application fertilizer through soil was 15.24 per cent.

Table.1 Effect of precision farming technology involving fertigation and mulching on growth and seed yield (q/ha) of okra Var. Arka Anamika

\begin{tabular}{|c|c|c|c|c|c|c|c|c|}
\hline Treatment & $\begin{array}{l}\text { Plant } \\
\text { height } \\
\text { cm) }\end{array}$ & $\begin{array}{l}\text { Stem } \\
\text { girth } \\
\text { cm) }\end{array}$ & $\begin{array}{l}\text { No of } \\
\text { branches }\end{array}$ & $\begin{array}{l}\text { Days to } \\
\mathbf{5 0} \\
\text { Flowering }\end{array}$ & $\begin{array}{l}\text { Leaf area } \\
\text { index }\end{array}$ & $\begin{array}{l}\text { Number } \\
\text { of fruits }\end{array}$ & $\begin{array}{l}\text { Dry fruit } \\
\text { weight } \\
\text { (g/fruit) }\end{array}$ & $\begin{array}{l}\text { Seed } \\
\text { yield } \\
\text { (q/ha) }\end{array}$ \\
\hline $\mathbf{T}_{\mathbf{1}}$ & 111.11 & 4.40 & 2.97 & 41.00 & 2.49 & 11.67 & 9.15 & 12.28 \\
\hline $\mathbf{T}_{\mathbf{2}}$ & 109.02 & 4.32 & 2.63 & 41.00 & 2.66 & 11.33 & 9.50 & 11.51 \\
\hline $\mathbf{T}_{\mathbf{3}}$ & 112.77 & 4.27 & 2.70 & 42.67 & 2.78 & 13.67 & 9.67 & 14.02 \\
\hline $\mathbf{T}_{\mathbf{4}}$ & 115.52 & 4.76 & 3.10 & 42.67 & 2.76 & 14.33 & 10.33 & 15.30 \\
\hline $\mathbf{T}_{\mathbf{5}}$ & 98.78 & 3.84 & 2.37 & 41.33 & 2.09 & 11.33 & 7.80 & 10.17 \\
\hline $\mathbf{T}_{\mathbf{6}}$ & 95.69 & 3.83 & 2.47 & 42.33 & 2.42 & 11.00 & 8.37 & 10.24 \\
\hline $\mathbf{T}_{\mathbf{7}}$ & 106.44 & 3.78 & 2.53 & 41.33 & 2.29 & 11.67 & 8.89 & 11.33 \\
\hline $\mathbf{T}_{\mathbf{8}}$ & 103.85 & 4.13 & 2.57 & 41.67 & 2.37 & 12.33 & 9.17 & 12.39 \\
\hline $\mathbf{T}_{\mathbf{9}}$ & 93.73 & 3.93 & 2.17 & 42.00 & 1.09 & 9.67 & 6.43 & 8.85 \\
\hline $\mathbf{T}_{\mathbf{1 0}}$ & 94.85 & 3.40 & 2.43 & 37.33 & 1.42 & 10.33 & 7.73 & 9.85 \\
\hline $\mathbf{S E m} \pm$ & 2.12 & 0.13 & 0.13 & -- & 0.10 & 0.44 & 0.33 & 0.67 \\
\hline $\mathbf{C D}$ at 5\% & 6.32 & 0.38 & 0.40 & NS & 0.30 & 1.32 & 1.00 & 1.99 \\
\hline
\end{tabular}


Fig.1

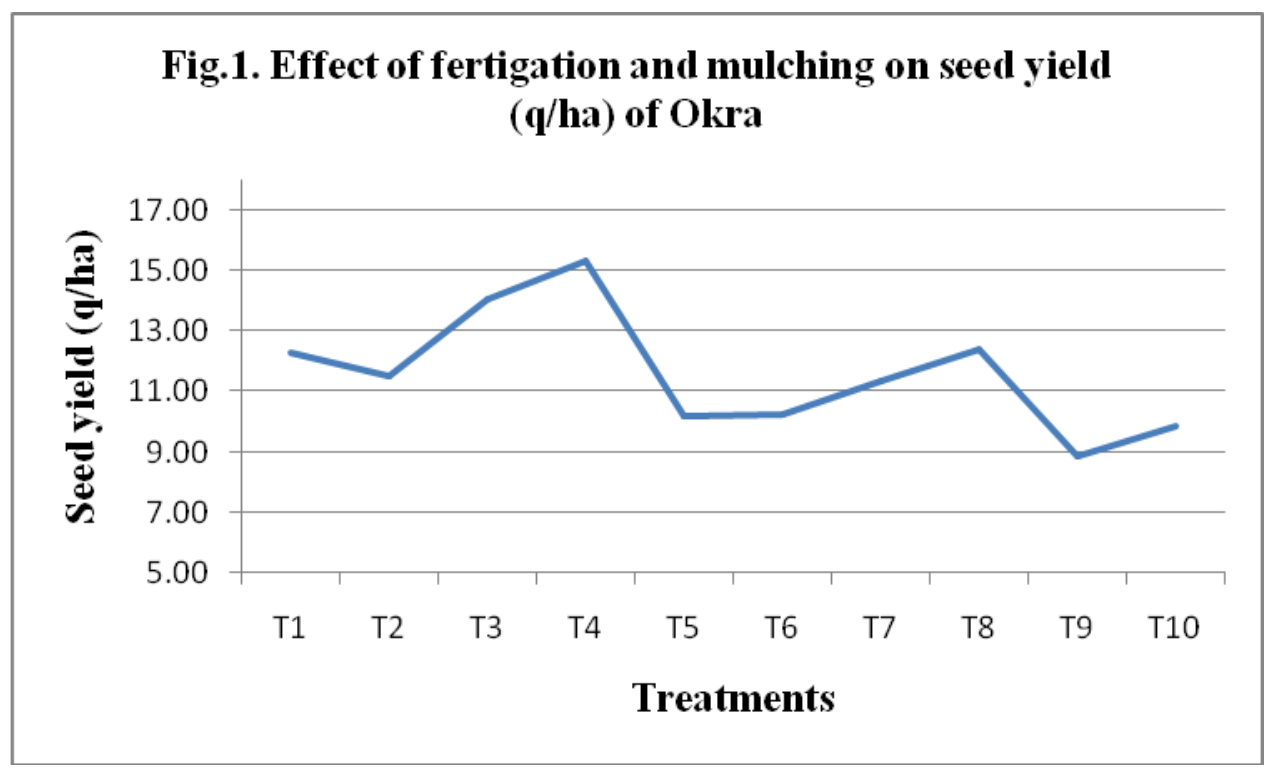

The increase in seed yield may be due to increased number of pods per plant and weight of dry fruits. Present study indicated significant response of plants to fertigation and mulching with respect to number pods per plant and weight of the dry fruit. With the application of fertilizer through fertigation with mulch $\left(\mathrm{T}_{4}-150: 75: 150 \mathrm{~N}: \mathrm{P}_{2} \mathrm{O}_{5}: \mathrm{K}_{2} \mathrm{O} \mathrm{kg}\right.$ $\mathrm{ha}^{-1}$ ) the number of fruits per plant was 14.33 compared to the treatment without mulch (12.33) $\mathrm{T}_{8}-150: 75: 150 \mathrm{~N}: \mathrm{P}_{2} \mathrm{O}_{5}: \mathrm{K}_{2} \mathrm{O} \mathrm{kg} \mathrm{ha}^{-1}$ through fertigation (WSF).

However, minimum number of fruits was observed in the treatment $\mathrm{T}_{9}(9.67)$ and $\mathrm{T}_{10}$ (10.33). Similar trend also observed in weight of the dry fruit. The maximum weight of dry fruits $(10.33 \mathrm{~g})$ was found in the treatment $\mathrm{T}_{4}$ over the un-mulched fertigation treatment $\mathrm{T}_{8}$ which recorded $9.17 \mathrm{~g}$ of dry weight of fruits.

This results corroborated the findings of Mishra et al., (2009) where higher fruit length (47\%), single fruit weight (46\%) and flowering $(13 \%)$ were reported with irrigation and mulch over surface irrigation. Thirty per cent higher yield of okra was reported in fertigation as compared to surface irrigation by Tiwari et al., (1998). This result is also in agreement with the findings of Puneet sharma and Arun Kaushal (2015) with an observation that drip fertigation in okra saves 20 per cent to 61 per cent of water, increases yield by 13 per cent to 76 per cent besides fertilizer saving from 15 to 30 per cent as compared to traditional cultivation methods.

In conclusion, from the present investigation, it may be inferred that application of recommended dose of water soluble fertilizers @ 150:75:150 N: $\mathrm{P}_{2} \mathrm{O}_{5}: \mathrm{K}_{2} \mathrm{O} \mathrm{kg} \mathrm{ha}{ }^{-1}$ through fertigation with mulch throughout the period is essential for realising higher seed yield in okra in general and var. Arka Anamika in particular. Mulch had a significant effect on seed yield attributing characters as compared to non mulched treatments. Hence, using mulch will certainly enhance seed yield.

The percentage increase of okra seed yield in mulched treatment over the un-mulched treatments with fertigation was around 16.90 per cent. Similarly the percentage increase of seed yield in treatments of fertigation without mulch over application fertilizer through soil was around 15.20 per cent. 


\section{References}

Agrawal, N and Agrawal, S. Effect of drip irrigation and mulches on the growth and yield of banana cv. Dwarf Cavendish. Indian. J. Hort., 62(3):238240.

Asiegbu, J.E. 1991. Response of tomato and egg plant to mulching and nitrogen fertigation under tropical conditions. Sci. Hortic., 46:33-41.

Hazarika, B.N. and S.Ansari.2010. Effect of integrated nutrient management on growth and yield of banana cv Jahaji 2010. Indian J. Hort., 67(2): 270-273.

Mahesh Babarao Ghuge, Rajesh Lekhi, Shraddha Karcho and Anil Kumar.2015. Influence of integrated Nutrient Management on Growth and Seed Yield of Okra [Abelmoschus esculentus (L.) Moench] cv VRO-6. Enviornment and Ecology, 33(3):1073-1076.

Mishra, J.N., Paul, J.C. and Pradhan, P.C. 2009. Response of okra to drip irrigation and mulching in coastal Orissa. Ind. J. Soil Cons. 37 (2):129132.

Pattanaik, S.K., Sahu, N.N., Pradhan, P.C. and Mohanty, M.K. 2003. Response of banana to drip irrigation under different irrigation designs. J. agric. eng., ISAE, 40(3):29-34.

Puneet Sharma and Arun Kaushal. 2015. Growing okra with drip fertigation-a review. Int. J. eng. sci. invention ISSN (Online). 4(9): 2319 - 6734.

Rai, M. and Pandey, A.K. 2008. Vegetable sector: growing with nation Agriculture year book 2008. Agriculture Today, New Delhi. pp 66-72.

Samuel, J.C. and Singh, H.P.2004. Perspective of Hi-tech horticulture and precision farming. In training Manual on precision farming in Horticulture. Ed. Panda, S.C. Patnaik, K.K., Mishra, J.N. Pradhan P.C. and Alim, M.A., PFDC, OUAT, Bhubaneshwar

Sanchita Brahma, Luchon Saikia, Tridip Kr. Hazarika and Pankaj Barua. 2014. Response of Capsicum (Capsicum annum Var. grossum) to different levels of $\mathrm{N}$ and $\mathrm{K}$ fertigation under Assam conditions. Progressive Hort., 46(1):8084.

Sharma, R.2002. Effect of nitrogen sources on growth, yield and quality of banan cv. Barjahaji (Musa- AAA group, Cavendish sub group), Ph.D thesis, Assam Agricultural University, Jorhat.

Shrivastava,P.K. Parikah, M.M. Sawani, N.G. and Raman, S. 1994. Effect of drip irrigation and mulching on tomato yield. Agric Water Manag., 25:179-184.

Thakur, P.S. Thakur,A. and Kanaujia,S.P. 2000. Reversal of water stress effects I. Mulching impacts on the performance of capsicum annuum under water deficit. Indian J. Hort., 57: 250-54

Tiwari, K.N., Mal, P.K., Singh, R. M. and Chattopadhyay, A. 1998. Response of okra [Abelmoschus esculentus (L.) Moench] to drip irrigation under mulch and non mulch condtions. Agric Water Manag.,

35:201-207.

\section{How to cite this article:}

Nagegowda, N.S., T. Senthivel, S. Shankar Hebbar and Senthilkumar, M. 2019. Effect of Precision Farming Techniques Involving Fertigation and Mulching on Growth Attributes and Seed Yield of Okra Var. Arka Anamika [Abelmoschus esculentus (L.) Moench]. Int.J.Curr.Microbiol.App.Sci. 8(02): 2502-2507. doi: https://doi.org/10.20546/ijcmas.2019.802.291 